Razin, S. \& Knight, B. C. J. G. (1960). J. gen. Microbiol. 22, 504-519

\title{
The Effects of Ribonucleic Acid and Deoxyribonucleic Acid on the Growth of Mycoplasma
}

\author{
By S. RAZIN and B. C. J. G. KNIGHT \\ Department of Microbiology, University of Reading
}

SUMMARY: The nucleic acid requirements of several Mycoplasma organisms were examined in a partially defined medium. The saprophytic $M$. laidlawii strain A did not grow in the basal medium alone (Razin \& Knight, 1960 $a$ ) but did when suitable concentrations of ribonucleic acid (RNA) and of deoxyribonucleic acid (DNA) were added. Too high a concentration of RNA inhibited growth; this inhibition was annulled by increasing the concentration of DNA. Similarly, too high a concentration of DNA inhibited growth, and this inhibition was annulled by RNA. Chemical and enzymic degradations of RNA showed that the growth-promoting effect could be brought about by a ribo-oligonucleotide but not by smaller fragments of the molecule. Similar degradations of DNA showed that the effective moiety was thymidine; thymine was less effective. The degradation of RNA abolished its growth-inhibitory activity. The growth-inhibitory activity of DNA was not affected by its degradation to oligonucleotides, and was only partially diminished by its degradation to nucleotides or nucleosides.

Mycoplasma laidlarvii strain B grew in the basal medium when DNA alone was added. This nutritional requirement was also satisfied by thymidine, provided that some RNA was also present. The parasitic Mycoplasma mycoides var. capri resembled $M$. laidlareii strain B in responding to DNA alone, but differed from the saprophytic strains in its complete indifference to high DNA concentrations. Thymidine replaced DNA only to a certain extent when added together with RNA. A growth-promoting effect of DNA was also found with the L-phase of Streptobacillus moniliformis; thymidine then replaced DNA completely. The RNA/DNA antagonism was found with all the organisms examined. Possible explanations for this phenomenon are discussed.

Information about the effects of nucleic acids and their fragments on the growth of Mycoplasma organisms is very scanty. Edward \& Fitzgerald (1952) found that certain bovine strains needed DNA to be added to a complex medium for primary culture; work by Crowther \& Knight (1956) indicated that DNA acted here by annulling a growth inhibitory effect caused by the RNA present in the yeast extract used in the complex Edward medium (Edward, 1947). The growth-inhibitory activity of RNA and the activity of DNA in annulling this were destroyed by chemical or enzymic degradation of the polynucleotides to mononucleotides. No explanation of these observations could then be given, as practically nothing was known about the nutritional requirements of the Mycoplasma organisms in regard to nucleic acids and their constituent parts. The complex nature of the medium then used prevented analysis of such requirements. The partially defined medium for Mycoplasma organisms described by Razin \& Knight $(1960 a)$ has now been found adequate for a

\footnotetext{
* Present address : Department of Clinical Microbiology, Hebrew University, Hadassah Medical School, Jerusalem, Israel.
} 
closer examination of the effect of nucleic acids on the growth of these organisms. The RNA/DNA antagonism can be demonstrated with this medium; this has permitted further analysis of the phenomenon and a possible interpretation of it.

\section{METHODS}

Organisms. The Mycoplasma strains were those previously used (Razin \& Knight, $1960 a$ ). The stable L-phase of Streptobacillus moniliformis was kindly given by $\mathrm{Dr} \mathrm{E}$. Klieneberger-Nobel (The Lister Institute for Preventive Medicine, London). Mycoplasma laidlawii strain A was used as the main test organism.

Media. A modified Edward medium (Butler \& Knight, 1960b) was used for keeping stock cultures and for growing the organisms used as inoculum in the nutrition experiments. The same medium, solidified with $2 \%(\mathrm{w} / \mathrm{v})$ agar, was used for viable counts (Butler \& Knight, 1960a).

The nutrition experiments were carried out in the partially chemically defined medium described previously (Razin \& Knight, 1960a; Table 1). This medium without added ribonucleic and deoxyribonucleic acids will be referred to as basal medium. For experiments with Mycoplasma mycoides var. capri and the L-phase of Streptobacillus moniliformis the basal medium was fortified by increasing the serum to $20 \%(\mathrm{v} / \mathrm{v})$ and adding yeast extract (Oxoid) to $0.05 \%(w / v)$.

Pyrex glassware was used in al Jexperiments; before use it was cleaned in chromic + sulphuric acid mixture and thoroughly rinsed in distilled water. The basal medium was dispensed in $9.5 \mathrm{ml}$. volumes into 6 in. $\times \frac{5}{8}$ in. test tubes; the solutions of nucleic acids or degradation products thereof to be tested were added to give a final volume of $10 \mathrm{ml}$. The nucleic acid solutions were sterilized by passage through sintered-glass filters or by steaming for $20 \mathrm{~min}$. (Merrifield $\&$ Dunn, 1950). Sterilization of the nucleic acid degradation products was done by steaming only. For bioassay all solutions of nucleic acid degradation products were made up to known volumes so that their activities could be related to the initial amounts of nucleic acid from which they were made.

Conditions of growth. The inoculum used in the experiments was prepared as described previously (Razin \& Knight, 1960a). In most experiments the inoculated test tubes were incubated vertically without agitation in air at $37^{\circ}$, but some experiments were done in $\perp$-shaped tubes (van Heyningen \& Gladstone, 1953) which were rocked in a $37^{\circ}$ water bath. Growth was usually estimated after incubation for $96 \mathrm{hr}$.

Assessment of growth. The methods described previously (Razin \& Knight, $1960 a$ ) were used, generally the acid titration method.

Chemicals. Most of the inorganic and organic chemicals were analytical reagents. Ribonucleic acid, $\mathrm{Na}$ salt from yeast (Na-RNA) was the product of L. Light and Co. Ltd., Colnbrook, Bucks.; it was further purified by the method of Frisch-Niggemeyer \& Reddi (1957). Deoxyribonucleic acid, Na salt from thymus gland (Na-DNA) was from the British Drug Houses Ltd., Poole, Dorset. Other samples of nucleic acids tested were: ribonucleic acid Na salt 
from yeast (British Drug Houses Ltd.); deoxyribonucleic acid Na salt (thymus) and deoxyribonucleic acid Na salt (from herring roe; L. Light and Co. Ltd.). The purines, pyrimidines, ribonucleosides, deoxyribonucleosides, ribonucleotides and deoxyribonucleotides used were commercial products. Ribonuclease (RNAse, crystallized, bovine pancreas) was from Armour Laboratories, Hampden Park, Eastbourne, Sussex, England. Deoxyribonuclease (DNAse, $\mathbf{2 5} \%$ activity of crystalline) was from L. Light and Co. Ltd. Freeze-dried Russell viper venom was the gift of the Wellcome Research Laboratories, Beckenham, Kent, through Mr H. Proom.

Analytical methods. The enzymic degradations of RNA and DNA were followed by estimating the total acid-soluble phosphorus liberated (McDonald, 1955; Butler, 1955), and by paper chromatography of the reaction mixtures (Markham, 1957). Whatman no. 1 paper and the isopropanol+ammonia system(solvent 3; Markham \& Smith, 1952) were used. The spots were detected under ultraviolet irradiation. Commercial purines, pyrimidines, nucleosides and nucleotides served as markers.

All samples taken for bioassay from the enzymic degradation experiments were immediately frozen at $-\mathbf{2 0}^{\circ}$.

\section{Degradation of ribonucleic acid}

Acid hydrolysis to oligonucleotides. This was done by the method of Merrifield \& Woolley (1952). A Na-RNA solution (140 mg./ml.) was brought to $\mathrm{pH} 6 \cdot 8$ by adding $\mathrm{N}-\mathrm{NaOH}$; a sample was removed at zero time. An equal volume of concentrated $\mathrm{HCl}$ was then added to the remainder of the solution with stirring and the mixture placed in a water bath at $25^{\circ}$. After $1,3,7,15$ and $30 \mathrm{~min}$. samples of the mixture were removed, diluted with 50 vol. ice-cold distilled water, neutralized with $\mathrm{NaOH}$, and made to volume for bioassay. A sample of the RNA $+6 \mathrm{~N}-\mathrm{HCl}$ mixture, incubated at $25^{\circ}$ for $3 \mathrm{~min}$., was dialysed in a cellophan bag (Visking, 0.85 in.) against distilled water for $24 \mathrm{hr}$. at room temperature. The dialysate and diffusate were tested for biological activity.

Degradation by RNAse to oligonucleotides and pyrimidine mononucleotides. On e mg. RNAse was added per $\mathrm{ml}$. Na-RNa solution $(50 \mathrm{mg} . / \mathrm{ml}$.). The mixture was brought to $\mathrm{pH} 8.0$ and incubated at $37^{\circ}$. Samples for bioassay and acidsoluble phosphorus determination (McDonald, 1955) were removed at zero time and after $0 \cdot 25,1 \cdot 5,3 \cdot 5,6,20$ and $30 \mathrm{hr}$. The reaction mixture was readjusted to $\mathrm{pH} 8.0$ when each sample was taken. The acid-soluble fraction of the RNA hydrolysate was obtained by mixing the sample of the reaction mixture, after incubation for $30 \mathrm{hr}$., with an equal volume of $\mathrm{N}-\mathrm{HCl}$. This produced a precipitate in the mixture which was centrifuged at $4^{\circ}$, the supernatant fluid neutralized by adding $6 \mathrm{~N}-\mathrm{NaOH}$ and kept for bioassay. Some of the reaction mixture, after incubation for $30 \mathrm{hr}$., was dialysed in a cellophan bag (Visking, $0.85 \mathrm{in}$.) against distilled water for $18 \mathrm{hr}$. at $4^{\circ}$ and then for $6 \mathrm{hr}$. at room temperature. The dialysate and diffusate were separately collected and tested for biological activity. Paper chromatography of the reaction mixture at the end of the incubation period showed the disappearance of undegraded 
RNA and the appearance of spots whose $R_{F}$ values corresponded with those of oligo- and mono-nucleotides (Markham, 1957).

Degradation of $R N A$ to nucleoside-5'-phosphates by phosphodiesterase from Russell viper venom. Purification of the phosphodiesterase from Russell viper venom was done by acetone fractionation of the crude venom according to the method of Sinsheimer \& Koerner (1952). Purified enzyme preparation $(1.5 \mathrm{ml}$.) was then added to $10 \mathrm{ml}$. of the RNA + RNAse reaction mixture which had been pre-incubated at $37^{\circ}$ for $30 \mathrm{hr}$., then $\mathrm{MgCl}_{2} \cdot 6 \mathrm{H}_{2} \mathrm{O}$ was added to a final concentration of $0.025 \mathrm{M}$ and the solution brought to $\mathrm{pH} 9.3 \mathrm{by} \mathrm{N}$ $\mathrm{NaOH}$. Further incubation was then carried out at $37^{\circ}$ and samples for bioassay and acid-soluble phosphorus determinations (Butler, 1955) were removed at zero time and after 5.5 and $22 \mathrm{hr}$. The reaction mixture was readjusted to pH 9.3 at frequent intervals. Paper chromatography of the reaction mixture at the end of the incubation period showed spots with $\boldsymbol{R}_{\boldsymbol{F}}$ values corresponding to mononucleotides and nucleosides. The presence of the nucleosides may be explained by contamination of the enzyme preparation with phosphomonoesterase which was not completely eliminated by the purification method used (Privat de Garilhe \& Laskowski, 1955).

Degradation to nucleosides by Russell viper venom. This was carried out by a modification of the method of Cohn (1957). Na-RNA (400 mg.) was dissolved in $10 \mathrm{ml} .0 .01 \mathrm{M}-\mathrm{MgCl}_{2} \cdot 6 \mathrm{H}_{2} \mathrm{O}$ solution. Freeze-dried Russell viper venom (20 mg.) was added and the mixture brought to $\mathrm{pH} 9.0$ by $\mathrm{N}-\mathrm{NaOH}$. Incubation was at $37^{\circ}$ and samples for bioassay and acid-soluble and inorganic phosphorus determinations (Butler, 1955) were removed at zero time and after 1, 6 and $24 \mathrm{hr}$. The mixture was readjusted to $\mathrm{pH} \mathrm{9.0} \mathrm{at} \mathrm{frequent} \mathrm{intervals} \mathrm{during}$ incubation. Paper chromatography of a sample taken at the end of the reaction showed the presence of nucleosides only.

Alkaline hydrolysis to nucleoside-2'-and $-\mathbf{3}^{\prime}$-phosphates. Na-RNA (450 mg.) was dissolved in $30 \mathrm{ml} .0 .5 \mathrm{~N}-\mathrm{NaOH}$ and the solution incubated at $25^{\circ}$. Samples were removed at zero time and after incubation for $0.25,0.5,1,2,4$, $7 \cdot 5$ and $27 \mathrm{hr}$. The samples were neutralized immediately with $\mathrm{N}-\mathrm{HCl}$ and made to volume for bioassay. Paper chromatography of a sample taken at the end of the reaction showed the complete disappearance of RNA and the appearance of mononucleotides.

Acid hydrolysis to purine bases and pyrimidine nucleotides. This was carried out according to Schmidt (1957), equal volumes of Na-RNA solution (28 mg./ ml.) and $3 \mathrm{~N}-\mathrm{H}_{2} \mathrm{SO}_{4}$ being mixed and placed in a boiling water bath for $1 \mathrm{hr}$.; the test tube containing the mixture was closed with a glass bulb. After cooling the solution was neutralized by $6 \mathrm{~N}-\mathrm{NaOH}$ and tested for biological activity.

\section{Degradation of deoxyribonucleic acid}

Apurinic acid was prepared by a mild acid treatment of DNA (Tamm, Hodes \& Chargaff, 1952).

Degradation by $D N A$ se to oligonucleotides. DNAse (1 mg. $/ \mathrm{ml}$.) was added to a $0.025 \mathrm{M}-\mathrm{MgSO}_{4} \cdot 7 \mathrm{H}_{2} \mathrm{O}$ solution containing $50 \mathrm{mg}$. Na-DNA $/ \mathrm{ml}$. The solution 
was adjusted to $\mathrm{pH} 6.8$ and incubated at $37^{\circ}$ for $25 \mathrm{hr}$. Samples for bioassay and acid-soluble phosphorus determinations (McDonald, 1955) were taken at zero time and after 2,6 and $26 \mathrm{hr}$. The reaction mixture was readjusted to pH 6.8 when samples were withdrawn. After incubation for $8 \mathrm{hr}$., more DNAse was added ( $0.5 \mathrm{mg} . / \mathrm{ml}$. solution). Paper chromatography of a sample taken at the end of incubation showed spots corresponding mainly to oligonucleotides. Some of the DNA + DNAse mixture was taken at the end of the incubation period and dialysed against distilled water at $4^{\circ}$ for $48 \mathrm{hr}$. The dialysate and diffusate were tested for biological activity. No precipitate was formed when an equal volume of $\mathrm{N}-\mathrm{HCl}$ was added to the DNA + DNAse mixture at the end of the incubation period, indicating that all the DNA was degraded to smaller fragments (Schmidt, 1957).

Degradation to deoxynucleotides by phosphodiesterase from Russell viper venom. Phosphodiesterase preparation $(1.5 \mathrm{ml}$.) was added to $5 \mathrm{ml}$. DNA+DNAse mixture which had been pre-incubated at $37^{\circ}$ for $26 \mathrm{hr}$. The solution was brought to $\mathrm{pH} 9.3$ by $\mathrm{N}-\mathrm{NaOH}$ and incubated at $37^{\circ}$ for $24 \mathrm{hr}$. Samples for bioassay and acid-soluble phosphorus determinations were taken at zero time and after 6 and $24 \mathrm{hr}$. The solution was readjusted to $\mathrm{pH} 9 \cdot 3$ at frequent intervals during incubation. Paper chromatography of samples taken during the reaction period showed the disappearance of the oligonucleotides and the appearance of mononucleotides. At the end of the reaction spots corresponding to nucleosides also appeared.

Degradation of DNA to deoxynucleosides by Russell viper venom. To $6 \mathrm{ml}$. DNA + DNAse mixture, which had been pre-incubated at $37^{\circ}$ for $26 \mathrm{hr}$., freezedried Russell viper venom (10 mg.) was added, the solution brought to $\mathrm{pH} \mathrm{9 \cdot 3}$ by adding $\mathrm{N}-\mathrm{NaOH}$ and further incubated at $37^{\circ}$. Samples for bioassay and acid-soluble and inorganic phosphorus determinations were taken at zero time and after 6 and $24 \mathrm{hr}$. During incubation the solution was readjusted to $\mathrm{pH} \mathbf{9 \cdot 3}$ at frequent intervals. A heavy white precipitate appeared at the end of the reaction. Paper chromatography showed the complete conversion of the oligonucleotides to nucleosides.

\section{RESULTS}

The effect of RNA and DNA on the growth of Mycoplasma laidlawii strain $A$ No growth of Mycoplasma laidlawii strain A took place in the basal medium alone; the addition together of suitable concentrations of RNA and DNA permitted growth. Too high a concentration of RNA inhibited growth; this inhibition was overcome by raising the concentration of DNA; and vice versa. Thus the growth inhibitory effects of RNA and DNA showed a mutual antagonism. The organism required RNA in higher concentrations than DNA (Table 1). No growth took place with $1 \mu \mathrm{g}$. Na-RNA/ml.; $5 \mu \mathrm{g}$. of Na-RNA/ml. allowed very poor growth. For optimal growth $50 \mu \mathrm{g}$. Na-RNA $/ \mathrm{ml}$. were needed, whereas $1 \mu \mathrm{g}$. Na-DNA/ml. was sufficient for suboptimal growth and maximal growth occurred with $25 \mu \mathrm{g}$. $/ \mathrm{ml}$. (Table 1 ).

Experiments in which growth was estimated by the viable count technique 
showed that the organisms survived in the medium without nucleic acids. Addition of RNA or DNA even in high concentrations did not kill the organisms (Fig. 1). The growth-promoting activities of RNA and DNA are not due to contaminating factors; purified or dialysed samples and nucleic acids from various sources showed the same effects.

Table 1. The effects of RNA and DNA on the growth of Mycoplasma laidlawii strain $A$

Test tubes contained $10 \mathrm{ml}$. basal medium supplemented with various amounts of NaRNA and Na-DNA. Initial inoculum was $5 \times 10^{4}$ viable particles $/ \mathrm{ml}$. Acid production was determined after incubation at $37^{\circ}$ for $96 \mathrm{hr}$. The numbers in heavy type indicate the optimal amounts of growth at different RNA and DNA concentrations.

Na-RNA $(\mu \mathrm{g} . / \mathrm{ml}$.

\begin{tabular}{|c|c|c|c|c|c|c|c|c|}
\hline \multirow{2}{*}{$\begin{array}{l}\text { Na-DNA } \\
(\mu \mathrm{g} . / \mathrm{ml} .)\end{array}$} & 0 & 1 & 5 & 25 & $\mathbf{5 0}$ & $\mathbf{2 5 0}$ & 500 & $\mathbf{2 5 0 0}$ \\
\hline & \multicolumn{8}{|c|}{ Acid production equiv. $0.01 \mathrm{~N}-\mathrm{NaOH}(\mathrm{ml} . / 10 \mathrm{ml}$. culture) } \\
\hline $\mathbf{0}$ & 0 & 0 & $\mathbf{0}$ & 0 & $\mathbf{0}$ & $\mathbf{0}$ & $\mathbf{0}$ & o \\
\hline 1 & $\mathbf{0}$ & $0 \cdot 4$ & $1 \cdot 6$ & $4 \cdot 4$ & $0 \cdot 4$ & $\mathbf{0}$ & $\mathbf{0}$ & 0 \\
\hline $\mathbf{5}$ & $\mathbf{0}$ & $\mathbf{0}$ & $2 \cdot 4$ & $\boldsymbol{7} \cdot \mathbf{0}$ & $7 \cdot 2$ & 0 & $\mathbf{0}$ & O \\
\hline 25 & 0 & 0 & $\mathbf{2} \cdot \mathbf{2}$ & 8.0 & 8.6 & $6 \cdot 0$ & $1 \cdot()$ & o \\
\hline 50 & 0 & 0 & $1 \cdot 6$ & $7 \cdot 2$ & $8 \cdot 4$ & 8.4 & $3 \cdot 0$ & $0 \cdot 6$ \\
\hline 250 & 0 & 0 & 0 & $4 \cdot 4$ & $5 \cdot()$ & $7 \cdot 2$ & 8.0 & $4 \cdot 2$ \\
\hline 500 & 0 & 0 & 0 & $2 \cdot 6$ & $2 \cdot 8$ & $6 \cdot 0$ & $5 \cdot 0$ & 6.0 \\
\hline 2500 & 0 & 0 & 0 & 0 & $1 \cdot 6$ & $2 \cdot 6$ & $2 \cdot 4$ & $3 \cdot 2$ \\
\hline
\end{tabular}

The effect of the degradation of RNA on its growth-promoting and DNA-antagonistic activities

Degradation of RNA to oligonucleotides by treatment with $6 \mathrm{~N}-\mathrm{HCl}$ for 3 min. at $25^{\circ}$ (Merrifield \& Woolley, 1952) did not significantly affect its growthpromoting activity. These active oligonucleotides passed through the cellophane during dialysis. Further hydrolysis of the oligonucleotides by longer treatment with acid rapidly abolished their growth-promoting activity.

Degradation of RNA by RNAse to oligonucleotides and pyrimidine mononucleotides (Davidson, 1957) decreased its growth-promoting activity. The products had no antagonistic activity against DNA $50 \mu \mathrm{g} . / \mathrm{ml}$. (Fig. 2). Dialysis of the degradation products showed the growth-promoting activity to be concentrated more in the diffusate than in the dialysate. The diffusate enabled even better growth than the undialysed RNA hydrolysate (Fig. 2). The acid-soluble fraction of the hydrolysate, which contains mononucleotides and small oligonucleotides (Schmidt, 1957), had the same activity as the diffusate.

Degradation of the oligonucleotides, obtained by RNAse treatment, to nucleoside- $5^{\prime}$-phosphates by Russell viper venom phosphodiesterase or to nucleosides by crude venom (Davidson, 1957) destroyed completely and very quickly their growth-promoting activity.

Alkaline hydrolysis of RNA to nucleoside-2' - and -3'-phosphates (Davidson, 1957) abolished its growth-promoting activity very quickly. The mixture of the mononucleotides obtained had no growth-inhibitory activity even when 
added at a final concentration equivalent to $2500 \mu \mathrm{g}$. Na-RNA/ml. to the basal medium containing optimal concentrations of Na-RNA and Na-DNA (50 $\mu \mathrm{g}$./ ml. of each). Hydrolysis of RNA to purine bases and pyrimidine nucleotides by $1.5 \mathrm{~N}-\mathrm{H}_{2} \mathrm{SO}_{4}$ at $100^{\circ}$ completely abolished its growth-promoting activity.

Mixtures of purines and pyrimidines (adenine, guanine, uracil, cytosine), nucleosides (adenosine, guanosine, uridine, cytidine), nucleosides-3' - phosphates (yeast adenylic acid, guanylic acid, uridylic acid, cytidylic acid) and their-5' phosphate isomers, were inactive in growth promotion, either alone or with $50 \mu \mathrm{g} . \mathrm{Na}-\mathrm{DNA} / \mathrm{ml}$. The purines and pyrimidines were tested in concentrations of 5 and $25 \mu \mathrm{g} . / \mathrm{ml}$. and the nucleosides, and nucleotides in concentrations of 10 and $100 \mu \mathrm{g} . / \mathrm{ml}$.

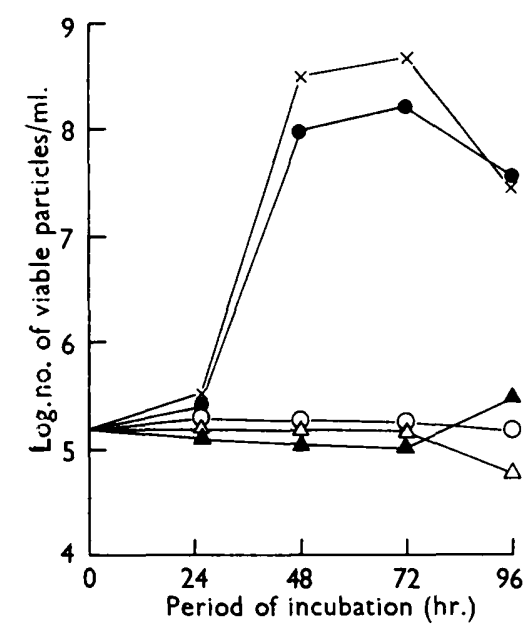

Fig. 1

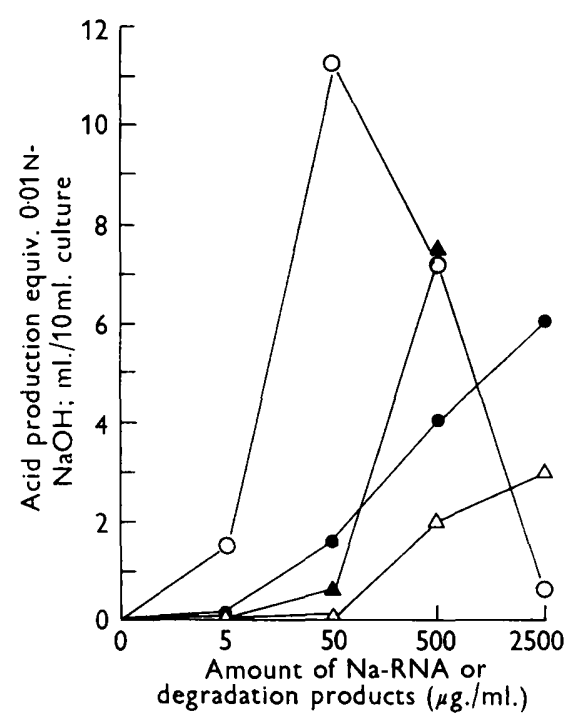

Fig. 2

Fig. 1. The effect of RNA and DNA on the growth of Mycoplasma laidlarvii strain A. $\perp$-Shaped tubes contained $10 \mathrm{ml}$. basal medium without nucleic acids $(O)$ or supplemented with : $500 \mu \mathrm{g} . / \mathrm{ml}$. Na-RNA $(\triangle) ; 500 \mu \mathrm{g} . / \mathrm{ml}$. Na-DNA $(\Delta) ; 500 \mu \mathrm{g} . / \mathrm{ml}$. Na-RNA $+500 \mu \mathrm{g} . / \mathrm{ml}$. Na-DNA $(0) ; 50 \mu \mathrm{g} . / \mathrm{ml}$. Na-RNA +50 $\mu \mathrm{g} . / \mathrm{ml}$. Na-DNA $(\times)$. The tubes were rocked in a $37^{\circ}$ water bath.

Fig. 2. The effect of degradation of RNA by RNAse on its growth-promoting activity for Mycoplasma laidlawii strain A. RNA was incubated with RNAse at $37^{\circ}$ for $30 \mathrm{hr}$. Part of the resulting hydrolysate was dialysed against distilled water. Test tubes contained $10 \mathrm{ml}$. basal medium supplemented with $50 \mu \mathrm{g}$. Na-DNA/ml. and various concentrations of : undegraded Na-RNA (O); hydrolysed RNA (O); dialysate of the hydrolysate $(\triangle)$; diffusate of the hydrolysate $(\Delta)$. Initial inoculum $1 \times 10^{5}$ viable particles $/ \mathrm{ml}$. Acid production determined after incubation at $37^{\circ}$ for $96 \mathrm{hr}$.

\section{The effect of the degradation of DNA on its growth-promoting and growth-inhibitory activities}

The mild acid treatment which removes the purine bases from the DNA molecule, giving the apurinic acid (Tamm et al. 1952) did not decrease the growth-promoting activity. High concentrations of apurinic acid showed, like DNA, growth-inhibitory activity. 
Degradation of DNA by DNAse to a mixture of oligonucleotides (Davidson, 1957) did not affect its growth-promoting activity and did not remove the growth inhibition shown by high concentrations (Fig. 3). The growth-promoting material in the hydrolysate was found in the diffusate on dialysis, and was not precipitated by $0.5 \mathrm{~N}-\mathrm{HCl}$. Thus, the growth-promoting activity of DNA is not dependent on the whole polynucleotide molecule.

Further degradation of the deoxyoligonucleotides to deoxynucleotides by Russell viper venom phosphodiesterase and to deoxynucleosides by the crude venom did not destroy the growth-promoting activity (Fig. 3). However, the activity in inhibiting growth at high concentrations was smaller. These results indicated that the growth-promoting effect of DNA resided in a moiety not

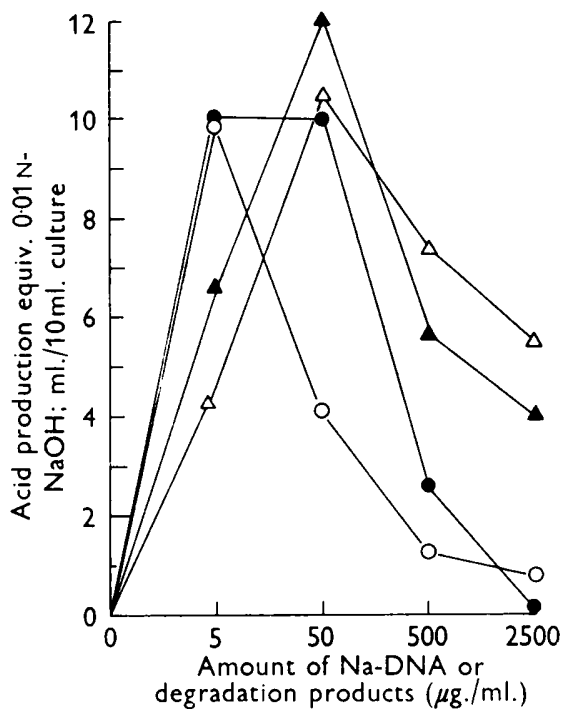

Fig. 3

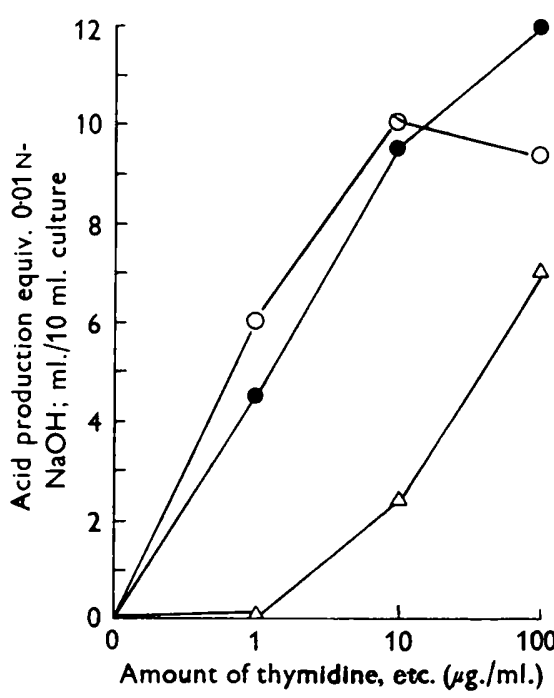

Fig. 4

Fig. 3. Various enzymic degradation products of DNA and their effect on growth of $M y c o-$ plasma laidlawii strain A. Test tubes contained $10 \mathrm{ml}$. basal medium supplemented with $50 \mu \mathrm{g}$. Na-RNA $/ \mathrm{ml}$. and different concentrations of : undegraded DNA (O); degradation products of DNA by DNAse $(O)$; degradation products of phosphodiesterase action $(\triangle)$; degradation products of action of crude snake venom $(\Delta)$. Initial inoculum $3 \times 10^{4}$ viable particles $/ \mathrm{ml}$. Acid production determined after incubation at $37^{\circ}$ for $96 \mathrm{hr}$.

Fig. 4. The growth response of Mycoplasma laidlawii strain $\mathbf{A}$ to thymidine and thymine. Test tubes contained $10 \mathrm{ml}$. basal medium supplemented with $50 \mu \mathrm{g}$. Na-RNA/ml. and various concentrations of: thymidine (O); thymidine + a mixture of the other deoxynucleosides and deoxynucleotides (each in the same concentration as thymidine) $(O)$; or thymine $(\triangle)$. Initial inoculum $3 \times 10^{4}$ viable particles $/ \mathrm{ml}$. Acid production determined after incubation at $37^{\circ}$ for $96 \mathrm{hr}$.

greater than a deoxynucleoside. The following deoxynucleosides and deoxynucleotides were tested for growth-promoting activity in the presence of $50 \mu \mathrm{g}$. Na-RNA/ml.: deoxyadenosine, deoxyguanosine, deoxyuridine, deoxycytidine, thymidine, deoxyadenylic acid, deoxycytidylic acid; the pyrimidine thymine was also tested. Only thymidine, and less effectively thymine supported 
growth (Fig. 4). The growth response of Mycoplasma laidlawii strain A to thymidine was even better than to DNA. Another phenomenon shown in Fig. 4 is the interference by high concentrations of other deoxynucleosides and deoxynucleotides with thymidine activity.

Thus the growth-promoting effects of RNA and DNA are shown, respectively, by the following moieties, namely, oligonucleotides probably less than tetranucleotides from RNA, and thymidine (thymine) from DNA; these appear to supply the minimal nutrient requirements. Smaller fragments are inactive. However, there still remains to be explained the antagonistic growth inhibitory effects shown by undegraded RNA and DNA.

\section{Possible mechanism of the RNA/DNA antagonism}

We chose as a working hypothesis the idea that high concentrations of RNA inhibit growth promoted by DNA by interfering with the enzymic degradation of DNA by the organism, which is a pre-requisite for the utilization of the DNA-thymidine, the real biosynthetic precursor. If this idea is correct then RNA should not have growth-inhibitory effects when the part of DNA which is the essential nutrient requirement of the organisms, i.e. thymidine, is included in the medium. This was found to be the case; Fig. 5 shows that high concentrations of RNA had no inhibitory activity when added to medium containing $10 \mu \mathrm{g}$. thymidine $/ \mathrm{ml}$. An experiment run simultaneously showed strong growth inhibition by high RNA concentrations when $50 \mu \mathrm{g}$. Na-DNA/ml. replaced thymidine in the medium.

However, the growth inhibitory effect of high concentrations of DNA or its degradation products cannot be explained by interference with RNA degradation by the organism, since DNA had the same growth inhibitory effects when added in high concentrations to the mixture of ribo-oligonucleotides (obtained by RNAse action) which apparently supply the minimal nutrient requirement of Mycoplasma laidlawii strain A as regards RNA.

The effects of RNA and DNA on the growth of Mycoplasma laidlawii strain $B$

Table 2 shows that Mycoplasma laidlarvii strain B, which is closely related to $M$. laidlawii strain A, differs from the latter in not requiring RNA. Addition of DNA itself enabled optimal growth when added in sufficient quantities. When the concentration of DNA was suboptimal $(5 \mu \mathrm{g} . / \mathrm{ml}$.) the addition of RNA improved growth. Apparently RNA supplies in this case components which are common to it and to DNA. As may be seen from Table 2 high concentrations of DNA inhibited the growth of $M$. laidlawii strain B; RNA did not overcome this inhibition. RNA showed the DNA-antagonizing effect when added in high quantities to low DNA concentrations, e.g. $5 \mu \mathrm{g} . / \mathrm{ml}$.; higher concentrations of DNA (50 $\mathrm{g} . / \mathrm{ml}$.) overcame this RNA inhibitory effect. Thymidine satisfied completely the nutritional requirement of $M$. laidlawii strain $B$ for DNA, provided RNA was also present. Optimal growth occurred with $10 \mu \mathrm{g}$. thymidine $/ \mathrm{ml}$. and $50 \mu \mathrm{g}$. Na-RNA $/ \mathrm{ml}$; ; even $1 \mu \mathrm{g}$. thymidine $/ \mathrm{ml} .+50 \mu \mathrm{g}$. Na-RNA/ml. supported good growth. 
The effects of RNA and DNA on the growth of Mycoplasma mycoides var. capri

In contrast to the saprophytic $M$ ycoplasma strains tested, $\boldsymbol{M}$. mycoides var. capri grew very poorly in the basal medium + Na-RNA + Na-DNA $(50 \mu \mathrm{g} . / \mathrm{ml}$. each). Increasing the concentration of serum from 10 to $20 \%(v / v)$ and addition of $0.05 \%(w / v)$ yeast extract (fortified medium) enabled good growth to occur. These changes in the composition of the basal medium did not mask the requirements for nucleic acids. Practically no growth of $\boldsymbol{M}$. mycoides var. capri took place in this fortified medium without added DNA; optimal growth

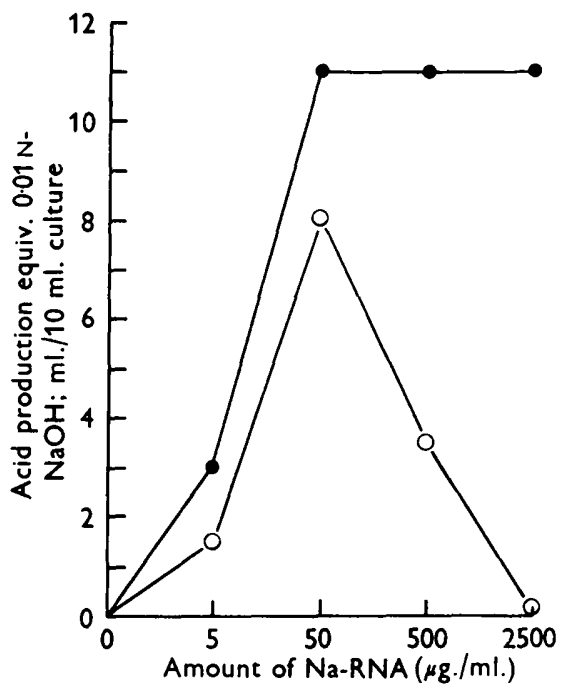

Fig. 5

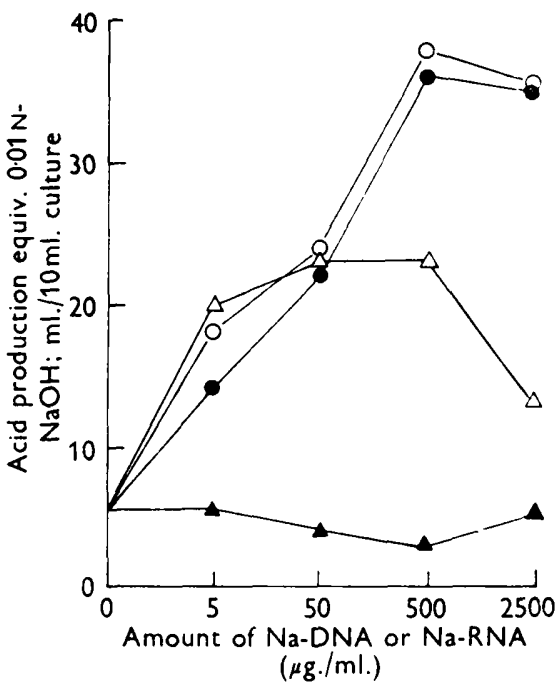

Fig. 6

Fig. 5. The effect of RNA on the growth of Mycoplasma laidlatcii strain $A$ in the presence of thymidine or DNA in the medium. Test tubes contained $10 \mathrm{ml}$. basal medium supplemented with $10 \mu \mathrm{g} . / \mathrm{ml}$. thymidine $(O)$ or $50 \mu \mathrm{g} . / \mathrm{ml}$. Na-DN. $(O)$ and different amounts of Na-RNA. Initial inoculum $1.7 \times 10^{5}$ viable particles $/ \mathrm{ml}$. Acid production determined after incubation at $37^{\circ}$ for $96 \mathrm{hr}$.

Fig. 6. The effects of RNA and INA on the growth of Mycoplasma mycoides var. capri. Test tubes contained $10 \mathrm{ml}$. fortified basal medium supplemented with various amounts of Na-RNA and Na-DNA. Na-DNA (O); Na-DNA + 50 $\mu \mathrm{g} . / \mathrm{ml}$. Na-RNA (O); Na-RNA $(\Delta) ;$ Na-RNA $+50 \mu \mathrm{g} . / \mathrm{ml}$. Na-DNA $(\triangle)$. Initial inoculum $2 \times 10^{6}$ viable particles $/ \mathrm{ml}$. Acid production determined after incubation at $37^{\circ}$ for $96 \mathrm{hr}$.

occurred only with high DN. concentrations. In contrast to the findings with the saprophytic $M$. laidlawii strains $A$ and B, DNA did not show any growthinhibitory effect in the highest concentration tested with $M$. mycoides var. capri (Fig. 6). With this organism thymidine replaced DNA only to a certain extent when added together with RNA. Increasing the concentration of thymidine depressed growth rather than improved it (Fig. 7 ). No requirement for RNA by $M$. mycoides var. capri could be shown in the fortified medium; however, RNA improved growth when added to suboptimal concentrations of DNA. High concentrations of RNA had the DNA-antagonistic effect (Fig. 6). 
Table 2. The effects of RNA and DNA on the growth of Mycoplasma laidlawii strain $B$

Test tubes contained $10 \mathrm{ml}$. basal medium supplemented with various concentrations of Na-RNA and Na-DNA. Initial inoculum $7 \times 10^{5}$ viable particles $/ \mathrm{ml}$. Acid production determined after incubation at $37^{\circ}$ for $96 \mathrm{hr}$.

The numbers in heavy type indicate the optimal amounts of growth at different RNA and DNA concentrations.

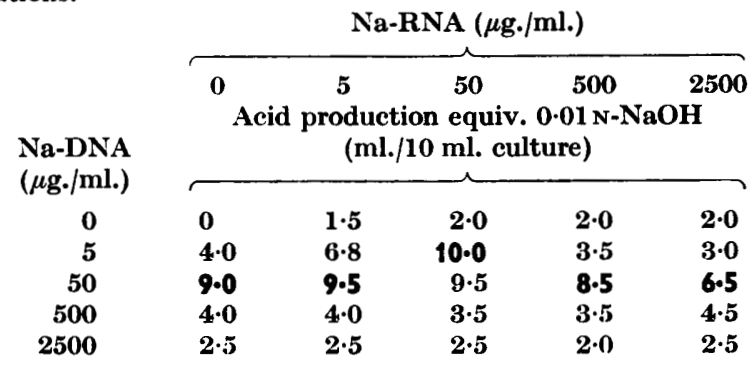

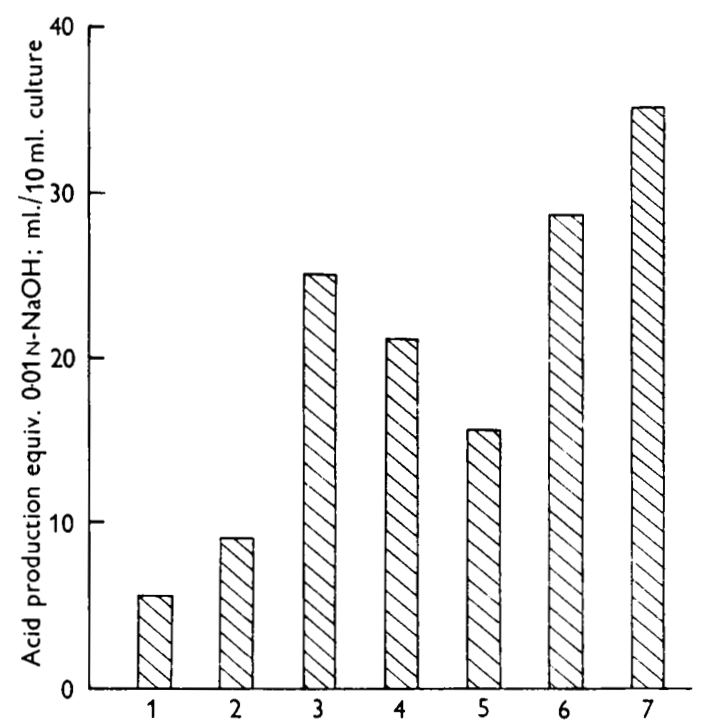

Fig. 7. The effect of thymidine on the growth of Mycoplasma mycoides var. capri. Experimental conditions as in Fig. 6. $1=50 \mu \mathrm{g} . / \mathrm{ml}$. Na-RNA; $2=20 \mu \mathrm{g} . / \mathrm{ml}$. thymidine; $3,4,5=50 \mu \mathrm{g}$. Na-RNA $/ \mathrm{ml} .+1,10$ or $100 \mu \mathrm{g}$. thymidine $/ \mathrm{ml}$., respectively; $6,7=$ $50 \mu$ g. Na-RNA $/ \mathrm{ml} .+50$ or $500 \mu \mathrm{g}$. Na-DNA $/ \mathrm{ml}$., respectively.

The effects of RNA and DNA on the growth of the stable L-phase of Streptobacillus moniliformis

It seemed interesting to determine whether the RNA/DNA antagonism could be demonstrated in organisms different from Mycoplasma spp. and indeed this RNA/DNA antagonism was shown with the L-phase of Streptobacillus moniliformis. This organism grew on the fortified basal medium when DNA was added; RNA was not required (Fig. 8). Optimal growth occurred even with small concentrations of DNA $(5 \mu \mathrm{g} . / \mathrm{ml}$.); higher concentrations of 
DNA decreased the amount of growth. RNA showed a clear DNA-antagonistic effect. Increasing the concentrations of RNA in the medium increased the concentration of DNA required for optimal growth. Thymidine $(1 \mu \mathrm{g} . / \mathrm{ml}$.) replaced DNA. In contrast to Mycoplasma mycoides var. capri $20 \mu \mathrm{g}$. thymidine/ml. were sufficient for optimal growth without any addition of RNA. It should be remembered that the fortified basal medium contained small amounts of RNA from the yeast extract.

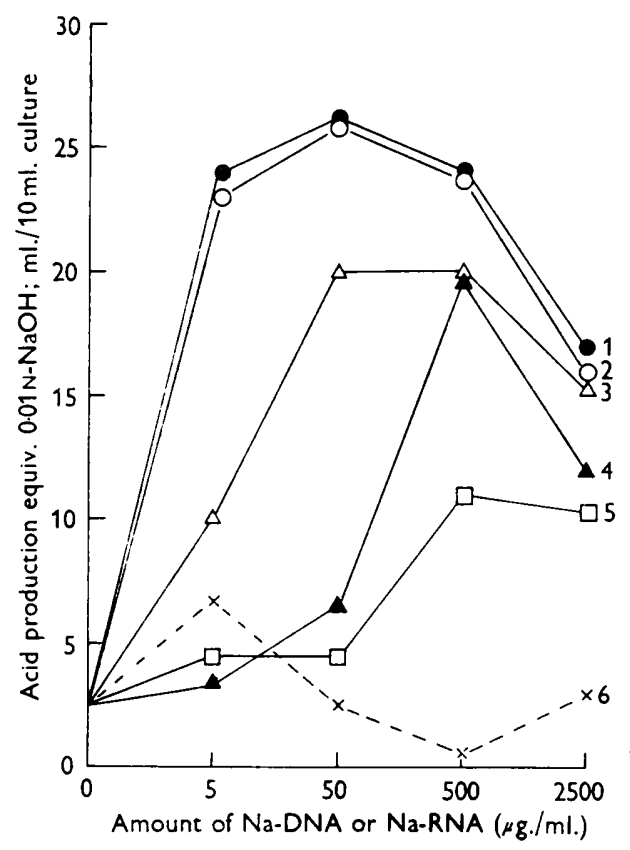

Fig. 8. The effects of RNA and DNA on the growth of the L-phase of Streptobacillus moniliformis. Experimental conditions as in Fig. 6. Initial inoculum $1 \times 10^{6}$ viable particles/ ml. $1=$ Na-DNA;2 = Na-DNA + 5 $\mu$ g. Na-RNA $/ \mathrm{ml} . ; 3=\mathrm{Na}-\mathrm{DNA}+50 \mu \mathrm{g} . \mathrm{Na}-\mathrm{RNA} /$ ml. $\quad 4=\mathrm{Na}-\mathrm{DNA}+500 \mu \mathrm{g}$. Na-RNA $/ \mathrm{ml} . ; \quad 5=\mathrm{Na}-\mathrm{DNA}+2500 \mu \mathrm{g}$. Na-RNA $/ \mathrm{ml}$.; $6=$ Na-RNA.

\section{DISCUSSION}

The Mycoplasma organisms were found to be capable of using for growth undegraded RNA and DNA which are presumably degraded to smaller fragments before they are used for biosynthesis. Mycoplasma mycoides var. mycoides contains RNAse (Plackett, 1957), but there is no information yet about the presence of RNAse and DNAse in other Mycoplasma organisms. However, DNAses are known to be widespread in many groups of micro-organisms (Catlin \& Cunningham, 1958). The possibility that RNA and DNA were degraded before utilization by enzymes present in the serum of the medium was ruled out by showing that growth was not affected by boiling the serum for $30 \mathrm{~min}$. before its addition to the medium.

The nutritional requirements for nucleic acid fragments were best defined with Mycoplasma laidlawii strain A. This organism requires as minimal 
essential nutrients thymidine (or less effectively, thymine) which can be derived from DNA, and one or more small oligonucleotides (di- or tri-nucleotides?) derived from RNA. The requirement for the ribo-oligonucleotide seems to be obligatory; it was not replaced by mononucleotides, nucleosides, purines or pyrimidines. This requirement for an oligonucleotide for growth would appear to indicate a deficiency in the biosynthetic ability of $M$. laidlawii strain A which is, at most, rarely found in bacteria.

All the Mycoplasma organisms tested were found to require something supplied by DNA. Thymidine replaced DNA with all the organisms tested except with $M$. mycoides var. capri. Thymidine seems to play an important role in the biosynthesis of DNA by these organisms. The formation of purine deoxyribosides from purine bases and thymidine, by the action of a deoxynucleoside phosphorylase of Mycoplasma organisms (Lynn, 1957), supports this assumption. The much better growth response obtained with the deoxyriboside thymidine than with its pyrimidine base is analogous with other findings; better utilization of nucleosides than their purine or pyrimidine bases has been described for several other micro-organisms (Loring \& Pierce, 1944; Hoffmann \& Pavcek, 1952; MacLeod, Hogenkamp \& Onofrey, 1958).

Strains A and B of Mycoplasma laidlawii differ serologically, but cannot be distinguished by cultural and biochemical properties (Edward, 1950). Our finding that strain $B$ differs from strain A by not requiring RNA (or oligonucleotide) as a nutrient is the first clue for a biochemical difference between these otherwise closely related strains.

We have found only one other example of the RNA/DNA antagonism in the literature, namely with Lactobacillus bifidus for which Skeggs, Spizizen \& Wright (1950) found that DNA (or derived nucleosides or nucleotides) was a nutrient requirement and that RNA antagonized growth promoted by DNA. In our case, however, the picture is more detailed. Mycoplasma laidlawii strain A needs its minimal nutrient requirements to be supplied by moieties of both DNA and RNA. When these moieties are supplied as undegraded RNA and DNA the antagonistic effect is shown by high concentrations of the polynucleotides. The growth inhibition caused by high concentrations of RNA or DNA may be due to interference with the preparation from these polynucleotides of the moieties required for biosynthesis. The growth inhibitory effect of RNA can be explained by its interference with preparatory degradation of DNA by the organisms (e.g. to release thymidine as a minimal biosynthetic precursor). RNA may inhibit competitively the degradation of DNA by the DNAse of the organisms; inhibition of microbial DNAses by RNA has been described (Bernheimer \& Ruffier, 1951; Catlin \& Cunningham, 1958). Indirect evidence in favour of this theory is the inability of RNA to inhibit growth when thymidine, which is the part of DNA needed by M. laidlawii strain A, is added to the medium instead of DNA. The observation that the degradation of RNA destroys its DNA-antagonistic activity also fits the theory; the whole RNA molecule is apparently necessary for an effective competition with DNA at the active sites of the organism's DNAse.

The growth inhibition caused by high DNA concentrations cannot, however, 
be explained in the same way, namely by interference with RNA utilization, since inhibition by DNA could be shown with organisms which did not require added RNA (or oligonucleotides) for growth. High DNA concentrations inhibited also the growth of Mycoplasma laidlawii strain $A$ when ribo-oligonucleotides were supplied instead of undegraded RNA. Degradation of DNA to deoxynucleotides and deoxynucleosides did not abolish the growth inhibitory activity. This might be explained by our observation that high concentrations of deoxynucleotides and deoxynucleosides interfered with the growthpromoting activity of thymidine, probably by competition at the active sites of biosynthetic enzymes. The interference of non-essential nucleotides and nucleosides with the utilization of the essential ones has been described, e.g. for Escherichia coli (Cohen \& Barner, 1957), a marine Flavobacterium (MacLeod et al. 1958) and for Lactobacillus acidophilus (Siedler \& Schweigert, 1959). The annulment of the growth inhibitory effect of high DNA concentrations by RNA might be explained by the interference by RNA with DNA degradation and therefore with the formation of interfering nucleotides and nucleosides. RNA could thus fulfil a regulatory function. The possibility that DNA might interfere with preparatory degradation of RNA by Mycoplasma laidlawii strain A, through inhibition of the RNAse of this organism, should also be kept in mind; inhibition of RNAse action by DNA was reported by McDonald (1955).

The RNA/DNA antagonism seems to be a general phenomenon and is not limited to Mycoplasma organisms. We observed it with the L-phase of Streptobacillus moniliformis and Skeggs et al. (1950) described it with Lactobacillus bifidus. It looks as if other micro-organisms which require some part of DNA as a precursor in biosynthesis, and which can degrade DNA for this purpose, might be inhibited by RNA when DNA is given in the culture medium as the source of this nutritionally essential moiety.

This work was begun by the late Stuart Crowther who supplied an invaluable basis from which our work was continued. It is our deep regret that his premature death prevented his exploiting it. We wish to acknowledge with sincere thanks the supply of cultures of Mycoplasma species by Dr D. G. ff. Edward and our valuable discussions with him. Similarly we wish to thank Dr E. Klieneberger-Nobel. One of us (S.R.) is indebted to the Friends of the Hebrew University of Jerusalem for the award of a Michael and Anna Wix Trust Fellowship. A grant from the Agricultural Research Council in support of this work is gratefully acknowledged.

\section{REFERENCES}

Bernheimer, A. W. \& Ruffier, N. K. (1951). Elaboration of deoxyribonuclease by streptococei in the resting state and inhibition of the enzyme by a substance extractable from the cocci. J. exp. Med. 93, 399.

Butler, G. C. (1955). Phosphodiesterase from snake venom. Methods in Enzymology, 2, 561. Ed. S. P. Colowick \& N. O. Kaplan. New York: Academic Press Inc.

BetLer, M. \& KNight, B. C. J. G. (1960a). The survival of washed suspensions of Mycoplasma. J. gen. Microbiol. 22, 470.

Butler, M. \& Knight, B. C. J. G. (1960b). The measurement of the growth of Myco. plasma in liquid media. J. gen. Microbiol. 22, 478.

Catlin, B. W. \& Conningham, L. S. (1958). Studies of extracellular and intracellular bacterial deoxyribonucleic acids. J. gen. Microbiol. 19, 522. 
Cohen, S. S. \& BARner, H. D. (1957). The conversion of 5-methyldeoxycytidine to thymidine in vitro and in vivo. J. biol. Chem. 226, 631.

Cons, W. E. (1957). Methods of isolation and characterization of mono- and polynucleotides by ion-exchange chromatography. Methods in Enzymology, 3, 724. Ed. S. P. Colowick \& N. O. Kaplan. New York: Academic Press Inc.

Crowther, S. \& KNight, B. C. J. G. (1956). The effect of nucleic acid fragments on the growth of a pleuropneumonia-like organism. J. gen. Microbiol. 14, p. vii.

Davidson, J. N. (1957). The Biochemistry of the Nucleic Acids, 3rd ed. London: Methuen and Co. Ltd.

EDward, D. G. FF. (1947). A selective medium for pleuropneumonia-like organisms. J. gen. Microbiol. 1, 238.

EDWARD, D. G. FF. (1950). An investigation of the biological properties of organisms of the pleuropneumonia group, with suggestions regarding the identification of strains. J. gen. Microbiol. 4, 311.

Edward, D. G. FF. \& Fitzgerald, W. A. (1952). A growth factor needed to isolate organisms of the pleuropneumonia group from the genital tract of cattle. Vet. Rec. 64, 395.

Frisch-Niggemeyer, W. \& Reddi, K. K. (1957). Studies of ribonuclease in tobacco leaves. I. Purification and properties. Biochim. biophys. Acta, 26, 40.

Heyningen, W. E. van \& Gladstone, G. P. (1953). The neurotoxin of Shigella shigae. III. The effect of iron on production of the toxin. Brit. J. exp. Path. 34, 221.

Hoffmann, H. A. \& Pavcek, P. L. (1952). Uridine as a growth factor for a strain of Streptococcus faecalis. J. Amer. chem. Soc. 74, 344.

Loring, H. S. \& Pierce, J. G. (1944). Pyrimidine nucleosides and nucleotides as growth factors for mutant strains of Neurospora. J. biol. Chem. 153, 61.

LYNN, R. J. (1957). Nucleic acid metabolism in pleuropneumonialike organisms. Bact. Proc. no. 126.

McDonaLD, M. R. (1955). Ribonucleases and deoxyribonucleases. Methods in Enzymology, 2, 427. Ed. S. P. Colowick \& N. O. Kaplan. New York: Academic Press Inc.

MacLeod, R. A., Hogenkamp, H. \& Onofrey, E. (1958). Nutrition and metabolism of marine bacteria. VII. Growth response of a marine flavobacterium to surface active agents and nucleotides. J. Bact. 75, 460.

Markham, R. (1957). Paper chromatography of mononucleotides and oligonucleotides. Methods in Enzymology, 3, 743. Ed. S. P. Colowick \& N. O. Kaplan. New York: Academic Press Inc.

Markham, R. \& Smith, J. D. (1952). The structure of ribonucleic acids. 1. Cyclic nucleotides produced by ribonuclease and by alkaline hydrolysis. Biochem. $J$. 52, 552.

Merrifield, R. B. \& DunN, M. S. (1950). The microbiological determination of pyrimidines with lactobacilli. J. biol. Chem. 186, 331.

Merrifield, R. B. \& Woolley, D. W. (1952). The structure and microbiological activity of some nucleotides isolated from yeast ribonucleic acid. J. biol. Chem. 197, 521.

PlacketT, P. (1957). Depolymerisation of ribonucleic acid by extracts of Asterococcus mycoides. Biochim. biophys. Acta, 26, 664.

Privat de Garilhe, M. \& Laskowski, M. (1955). Studies of the phosphodiesterase from rattlesnake venom. Biochim. biophys. Acta, 18, 370.

Razin, S. \& KNIGHT, B. C. J. G. (1960a). A partially defined medium for the growth of Mycoplasma. J. gen. Microbiol. 22, 492.

SснміDт, G. (1957). Chemical and enzymatic methods for the identification and structural elucidation of nucleic acids and nucleotides. Methods in Enzymology, 3, 747. Ed. S. P. Colowick \& N. O. Kaplan. New York: Academic Press Inc.

Siedler, A. J. \& Schweigert, B. S. (1959). Influence of ribonucleotides on the utilization of deoxyribonucleotides by Lactobacillus acidophilus. J. Bact. 77, 514. 
Sinsheimer, R. L. \& Koerner, J. F. (1952). A purification of venom phosphodiesterase. J. biol. Chem. 198, 293.

SkegGs, H. R., Spizizen, J. \& Wright, L. D. (1950). Competitive antagonism of ribonucleic and deoxyribonucleic acids in the nutrition of Lactobacillus bifidus. J. Amer. chem. Soc. 72, 811.

Tamm, C., Hodes, M. E. \& Chargaff, E. (1952). The formation of apurinic acid from the deoxyribonucleic acid of calf thymus. J. biol. Chem. 195, 49.

(Received 22 September 1959) 